\title{
Chest Physiotberapy in Cystic Fibrosis - Adjuncts and Alternatives
}

\author{
B. OBERWALDNER AND M. S. ZACH
}

\section{SUMMARY}

Chest physiotherapy is part of the long-term respiratory management of cystic fibrosis. Since compliance is often poor, effective and practical alternatives need to be sought.

A preliminary study investigated the effect of 7 weeks swimming training on the respiratory status of 10 patients while continuing their chest physiotherapy programme. Pulmonary function improved significantly after the course viz. FEV $: 82 \%$ predicted \pm 24 to $90 \%$ predicted $\pm 23, p<0,05$. Ten weeks after the trial most of the measurements had returned to their preswimming levels. It was noted that sputum production on swimming days was higher than on non-swimming days.

In a second study 12 children with cystic fibrosis participated in a training programme which included a variety of sports. Physiom therapy was discontinued during this period. Again pulmonary function improved significantly after the course viz. FEV $1: 71 \%$ predicted \pm 23 to $79 \%$ predicted $\pm 23, p<0,01$. Most values had returned to pre-training levels 8 weeks after the programme had ended.

A current study is investigating the possible therapeutic benefit of a one-way breathing valve with increased expiratory resistive loads. Preliminary results indicate increased mobilisation of obstructing secretions as well as a significant improvement of pulmonary function.

One can conclude that some highly effective. and practical adjuncts and alternatives to the daily physiotherapy routine for cystic fibrosis. do exist.

\section{OPSOMMING}

Borskas fisioterapie is deel van die langdurige respiratoriese hantering van sisties fibrose. Aangesien nakoming dikwels swak is, behoort doeltreffende en praktiese alternatlewe gesoek te word.

'n Voorlopige studie het die uitwerking ondersoek van 7 weke swemoefening op die respiratoriese staat van 10 pasiënte terwyl aangehou word met hul borskas-fisioterapieprogram. Pulmonere funksie het aansienlik verbeter ná die kursus, d.w.s. FEV: $82 \%$ voorspel \pm 24 tot $90 \%$ voorspel $\pm 23, p<0,05$. Tien weke ná die proefneming het meeste van die mate teruggekeer na hul voorswem vlakke. Dit was opgemerk dat sputumproduksie hoër was op swemdae as op nie-swemdae.

In 'n tweede studie het 12 kinders met sisties fibrose deelgeneem aan 'n oefeningsprogram wat ' $n$ verskeidenheid van sport ingesluit het. Fisioterapie was opgehef tydens hierdie periode. Weereens het pulmonère funksie aansienlik verbeter ná die kursus d.w.s. FEV 1 : 71\% voorspel \pm 23 tot $79 \%$ voorspel $\pm 23, p<0,01$. Meeste mate het na hul vooroefening vlakke teruggekeer 8 weke nadat die program geëindig het.

'n Huidige studie ondersoek die moontike terapeutiese voordeel van 'n eenrigting asem. halingsklep met verhoogde uitasemende weerstandbiedende ladings. Die voorlopige uitslae dul verhoogde mobilisasie van belemmerende sekresies aan sowel as 'n aansienlike verbetering van pulmonére funksie.

Dit kan afgelei word dat verskeie hoogs doeltreffende en praktiese byvoegsels en alternatiewe tot die daaglikse fisioterapie roetiene vir sisties fibrose pasiënte wel bestaan.
Beatrice Oberwaldner and Maximillian S. Zach.

Department of Paediatrics, University of Graz, Austria.

Paper read at Congess of the South African Society of Physiotherapy, Johannesburg, April 1985.

\section{INTRODUCTION}

Aerosol inhalation followed by PT has become a well established part of the lifelong therapeutic regimen in CF. In older children this programme can be extended by selfpercussion and forced expiration technique. The 
efficacy of this therapeutic approach is subject to scientific evaluation; the beneficial effect of some methods is already well documented.' Nevertheless there are practical drawbacks as this therapy is tedious, time-consuming and may decrease in efficacy when applied to the big, stiff chest of the adolescent and adult CF patient. Patient compliance is frequently poor in older children. Hence more popular and effective alternatives and adjuncts to this approach have to be sought.

Anecdotal evidence of a beneficial effect of physical exercise and sport stimulated this unit to undertake two relevant studies. ${ }^{2,3}$ A third study is concerned with the therapeutic effect of breathing against an external expiratory resistance.

$\begin{array}{ll}\text { Abbreviations used } \\ \text { CF: } & \text { Cystic Fibrosis } \\ \text { PT: } & \text { Chest physiotherapy } \\ \text { FVC: } & \text { Forced vital capacity } \\ \text { FEV }: & \text { Forced expiratory volume in one second } \\ \text { FEF }_{25-75:} & \text { Mean forced expiratory flow during middle } \\ & \text { half of FVC } \\ \text { PEFR: } & \text { Peak expiratory flow rate } \\ \text { RV: } & \text { Residual volume } \\ \text { TLC: } & \text { Total lung capacity } \\ \text { Vmax 25\%VC: } & \text { Maximum expiratory flow at 25\% remaining } \\ & \text { FVC } \\ \text { ERV: } & \text { Expiratory resistance valve } \\ \text { FVC/ERV: } & \text { Forced vital capacity with ERV } \\ \text { SEP: } & \text { Sustained expiratory pressure }\end{array}$

\section{Study I}

Eleven children with CF, 5 boys, 6 girls, age range 6 $3 / 12$ to $186 / 12$ years, participated in 17 swimming lessons over 7 weeks. The training consisted of floating, swimming, diving and various group games. For the entire training period the children collected and recorded their daily sputum volumes. Ventilatory status was assessed by spirometry before (A) and after this training period (B), as well as 10 weeks later (C). The PT routine of each child was maintained throughout the study.

As evident from Table 1, lung function improved with regular swimming and returned to pre-swimming levels thereafter. Only 6 children co-operated reliably with the sputum collection. When comparing sputum production on swimming and non-swimming days, two children had significantly higher volumes on swimming days. The summarised values of all 6 children were also significantly higher on swimming days.
In conclusion, this study demonstrated that swimming can improve ventilatory function in children with $\mathrm{CF}$, presumably by increased clearance of obstructing secretions. The beneficial effect seems to depend on the maintenance of swimming activities.

\section{Study II}

In the second study twelve children with CF, 6 boys, 6 girls, age range $24 / 12$ to $163 / 12$ years, participated in an intensive training programme of physical exercise and sport for 17 days. In the course of a CF summer camp, they hiked, jogged, participated in swimming lessons and in various sports and group games. In contrast to the previous study, their PT routine was discontinued for these 17 days. Twice daily each child recorded his PEFR. Ventilatory status was assessed in 10 children by spirometry and determination of lung volumes before (A) and after the course (B), and again 8 weeks later $(\mathrm{C})$.

As evident from Table 2 lung function improved with physical exercise and returned to pre-exercisef levels afterwards. RV/TLC showed a tendency to decrease with exercise; this decrease, however, did not reach statistical significance. Daily measurements of the PEFR showed an initial steep rise that coincided with a maximum of coughing and expectoration and was therefore most likely due to increased clearance of secretions. A second rise found towards the end of the course might have been a result of ventilatory muscle training.

In summary this study again demonstrated a beneficial effect of physical exercise on the ventilatory status of children with CF. Interrupting the PT routine for the training course did not alter the beneficial response.

\section{Study III}

Eleven children with CF, 5 boys and 6 girls, age range $91 / 12$ to $179 / 12$ years were trained to mobilize intrabronchial secretions by forced expiratory manoeuvres through an ERV attached to a tightly fitting rubber face mask. Expiratory resistance was varied by different size internal diameter plugs in the ERV-outlet. FVC/ERV was determined by connecting the outlet to a spirometer and was compared to thel FVC measured without the device. Eight different size resistance plugs were thus evaluated to determine the one with the highest FVC/ERV; simultaneously the SEP developed against the resistance was recorded.

$\begin{array}{lc} & \boldsymbol{A} \\ \text { FVC (\% predicted) } & 88 \pm 16 \\ \text { FEV }_{1}(\% \text { predicted) } & 83 \pm 24 \\ \text { FEF }_{25-75}(\% \text { predicted) } & 69 \pm 39 \\ \text { Values are mean } \pm 1 \text { SD } & \end{array}$

Values are mean $\pm 1 \mathrm{SD}$

Table 1. Lung function behaviour in Study I

$\begin{array}{cccc}A \text { vs. } B & B & B \text { vs. } C & C \\ \mathrm{p}<0,05 & 96 \pm 15 & \mathrm{p}<0,01 & 87 \pm 17 \\ \mathrm{p}<0,05 & 90 \pm 23 & \mathrm{p}<0,01 & 79 \pm 23 \\ \mathrm{p}<0,05 & 79 \pm 38 & \mathrm{p}<0,05 & 64 \pm 35\end{array}$

Table 2. Lung function behaviour in Study II

$\begin{array}{lccccc} & A & A \text { vs. } B & B & B \text { vs. } C & C \\ \text { FVC (\% predicted) } & 88 \pm 15 & \mathrm{p}<0,05 & 94 \pm 14 & \mathrm{NS} & 89 \pm 16 \\ \text { FEV }_{1} \text { (\% predicted) } & 71 \pm 22 & \mathrm{p}<0,01 & 79 \pm 23 & \mathrm{p}<0,01 & 73 \pm 23 \\ \text { FEF }_{25-75} \text { (\% predicted) } & 42 \pm 31 & \mathrm{p}<0,05 & 53 \pm 33 & \mathrm{p}<0,02 & 45 \pm 31 \\ \text { Values are mean } \pm \text { 1 SD, NS }=\text { not significant. } & & & \end{array}$


Table 3. Lung function behaviour in study III

\begin{tabular}{|c|c|c|c|c|c|c|c|}
\hline & $A$ & $A$ vs. $B$ & $B$ & $B$ vs. $C$ & C & $C$ vs. $D$ & $D$ \\
\hline $\mathrm{FEV}_{1} / \mathrm{FVC}(\%)$ & $67 \pm 14$ & $\mathrm{p}<0,05$ & $71 \pm 12$ & $\mathrm{p}<0,01$ & $65 \pm 14$ & NS & $67 \pm 13$ \\
\hline$V \max 25 \%$ VC (\% predicted) & $32 \pm 30$ & $\mathrm{p}<0,01$ & $52 \pm 34$ & $p<0,01$ & $20 \pm 22$ & $\mathrm{p}<0,05$ & $33 \pm 29$ \\
\hline RV/TLC & $43 \pm 15$ & $p<0,05$ & $39 \pm 13$ & $\mathrm{p}<0,001$ & $48 \pm 14$ & $\mathrm{p}<0,05$ & $44 \pm 16$ \\
\hline
\end{tabular}

Values are mean $\pm 1 \mathrm{SD}, \mathrm{NS}=$ not significant.

After a training from 1 to 6 months each child exceeded his/her FVC with the FVC/ERV, thereby indicating recruitment of previously shut-off areas of ventilation. FVC/ERV was $124 \%$ FVC $\pm 15(102-150)$ at an SEP of $64 \mathrm{~cm} \mathrm{H} \mathrm{H}_{2} \mathrm{O} \pm 31(26-120)$. Using the ERV children cleared a mean of $77 \%(21-100)$ of their daily sputum volume.

Multiple aspects of lung function were measured at the beginning of the study (A), after 10 months without PT but with use of ERV twice daily for 20 minutes (B), after two further months with PT and without ERV (C), and finally after 4 further months without PT and with $\operatorname{ERV}(\mathrm{D})$.

As evident from Table 3, there were increased expiratory volumes and flow rates and decreased hyperinflation with ERV and a decline of lung function without it. Two children transiently used a suboptimal resistance and responded with a deterioration of lung function.

In conclusion this study demonstrated that regular use of ERV improves lung function and mucus clearance in $C F$, seemingly by dilating airways distal to obstructing mucus plugs. Its use however, necessitates thorough practice and frequent control of optimal resistance and technique.

\section{DISCUSSION}

These results promise several new approaches to the treatment of impaired mucociliary clearance in CF.

Relevant to the therapeutic value of sports, some important questions remain unanswered and offer themselves for prospective studies. At present the relative value of different sports remains undefined. As shown in study I, swimming seems to be of special value. This might be owing to subtle submersion-induced alterations of ventilatory mechanisms as well as to exercise-induced hyperventilation of well moisturized air. Other investigators found lung function unchanged after 3 months of exercise training. ${ }^{4}$ However in their control group that did not exercise, pulmonary function had deteriorated significantly thereby most likely expressing the natural downhill course of the disease.

Another important concern refers to possible exercise-induced alterations in pulmonary gas exchange. Prolonged periods of exercise-induced hypoxemia should have a negative effect on pulmonary vascular resistance. It has been documented however that $\mathrm{CF}$ patients tend to maintain their resting arterial $\mathrm{pO}_{2}$ during exercise by means of an improved matching of ventilation and perfusion. ${ }^{5}$ Such beneficial effects might not occur regularly in children with advanced lung disease. $^{6}$

A further aspect of exercise and sports in CF refers to the positive psychological effects of participating and competing in group activities. Most CF children have previously been discouraged from exercising. Increased self-esteem and better social integration may be expected from this new and active approach.

While sport appears as an attractive adjunct to daily PT, its role as a possible substitute has some practical drawbacks. Sport is time-consuming, facilities may not be readily available, group activities may not always suit individual exercise tolerance and severely ill patients will frequently have to be excluded. Here the regular daily use of ERV offers an interesting new possibility. The device is small and handy, its efficacy in clearing secretions and improving lung function appears superior to conventional PT. Other investigators also report beneficial effects from the use of ERV.,8

\section{CONCLUSION}

There are efficient adjuncts and alternatives to conventional $P T$ in the long-term respiratory care for $C F$ patients. Practical clinical experience indicates wide inter-individual and longitudinal intra-individual differences in the effects of PT, sport and ERV. Therefore optimal management necessitates repeated assessment of all available methods for the individual CF patient.

\section{References}

1. Desmond KJ, Schwenk WF, Thomas E, Beaudry PH, Coates AL. Immediate and long-term effects of chest physiotherapy in patients with cystic fibrosis. $J$ Pediatr 1983; 103: 538-542.

2. Zach M, Purrer B, Oberwaldner B. Effect of swimming on forced expiration and sputum clearance in cystic fibrosis. Lancet 1981; ii: 1201-1203.

3. Zach M, Oberwaldner B, Hausler F. Cystic fibrosis: Physical exercise versus chest physiotherapy. Arch Dis Child 1982; 57: 587-589.

4. Orenstein DM, Franklin BA, Doershuk CF, Hellerstein HK, Germann KJ, Horowitz JG, Stern RC. Exercise conditioning and cardiopulmonary fitness in cystic fibrosis. Chest 1981; 80: 392-398.

5. Dantzker DR, Patten GA, Bower JS. Gas exchange at rest and during exercise in adults with cystic fibrosis. $A m R e v$ Respir Dis 1982; 125: 400-405.

6. Cropp GJ, Pullano TP, Cerny FJ, Nathanson IT. Exercise tolerance and cardiorespiratory adjustments at peak work capacity in cystic fibrosis. Am Rev Respir Dis 1982; 126: 211-216.

7. Groth S, Stafanger G, Dirksen H, Anderson JB, Falck M, Kjelstrup $M$. Change of lung volumes during positive expiratory pressure (PEP-mask) physiotherapy in cystic fibrosis. 1n: Lawson D, ed. Cystic Fibrosis: Horizons. Chichester - New York - Brisbane - Toronto - Singapore: J. Wiley and Sons, 1984: 249.

8. Stafanger G, Kramarz D, Falk M, Kelstrup M. Longterm study of effect of PEP-mask in cystic fibrosis patients. Proceedings 12th Annual Meeting European Working Group Cystic Fibrosis 1983: 272. 